Ellison, Brian A (Spring 1998). The advocacy coalition framework and implementation of the Endangered Species Act: a case study in Western water politics. Policy Studies

Journal, 26, n1.p.11(19)

\title{
The advocacy coalition framework and implementation of the Endangered Species Act: a case study in Western water politics
}

\begin{abstract}
:
Theories about subsystem activity typically focus on policy formulation processes. One causal model of public policymaking, the advocacy coalition framework, offers a potentially useful way to bridge the gap between policy formulation and implementation in examining subsystem activity. The purpose of this paper is to assess the analytical utility of the advocacy coalition framework by examining the stability of policy-producing coalitions over time in the face of implementation complexities. An analysis of the policy changes that occurred during the implementation of the Endangered Species Act vis-a-vis planning for the construction of the Bureau of Reclamation's Animas-La Plata water project is conducted. The analysis reveals how coalitions protect their policy core beliefs during technical disputes through the acquiescence of secondary aspects of belief systems.
\end{abstract}

\section{Introduction}

For the past 50 years scholarship on policy formulation has made much of the role that policy subsystems play in the economy of decisionmaking in American government. While ideas about the structure and permeability of subsystems have changed, moving from early concepts of rigid, iron triangles or subgovernments (Cater, 1964; Freeman, 1965; Griffith, 1939) to the broader notions of issue networks (Heclo, 1978) or advocacy coalitions (Sabatier, 1987), the basic idea persists that alliances among formal and informal actors are required to make public policy. But what happens to these alliances after public policies are made? Do the power relationships among coalitions that lead to the formulation of a public policy continue to exert a similar influence during implementation? How do power relationships change to address unanticipated complexity in implementation?

One problem with most theories of subsystem activity is that they are devoted to the explanation of events among actors during policy formulation. The classic subgovernment model, for example, seeks to explain policy formulation in distributive policy arenas, but stops short of explaining what happens after a congressional decision to build a dam or highway is made (McCool, 1990, 1997). Interestingly, Heclo's (1978) ideas about policy subsystems helped us 
broaden our thinking about informal alliances, but focused primarily on the benefits of protracted indecision to the members of issue networks.

One causal model of public policymaking offers a potentially useful way to bridge the gap between policy formulation and implementation in examining subsystem activity. The advocacy coalition framework (ACF) offers a mechanism to explain policy change over time and is based on the premises, among others, that policy subsystems are the most useful unit of analysis, and that a time perspective of a decade or more is needed to understand policy change (JenkinsSmith \& Sabatier, 1994, pp. 178-180; Jenkins-Smith, St. Clair, \& Woods, 1991; Sabatier \& Jenkins-Smith, 1993). Hence, the ACF gives researchers an opportunity to study subsystem dynamics through at least one formulation/implementation/reformulation cycle (Mazmanian \& Sabatier, 1989) and provides a benchmark, policy change, for understanding the ramifications of challenge to the stability of subsystems. A third premise of the ACF is that public policies are reflections of belief systems in that they incorporate values, priorities, causal theories, etc., of different subsystem participants (Jenkins-Smith \& Sabatier, 1994, pp. 178-180; Jenkins-Smith et al., 1991).

In a recent examination of California water supply policy, Munro (1993) found that the ACF provided a useful mechanism for explaining subsystem dynamics and policy formulation over a 50-year period. The purpose of this paper is to assess the analytical utility of the ACF by examining the stability of policy-producing coalitions over time in the face of implementation complexities. This purpose will be accomplished through an analysis of policy changes that occurred during the implementation of the Endangered Species Act (ESA) vis-a-vis planning for the construction of the Bureau of Reclamation's Animas-La Plata water project.

The Animas-La Plata case was chosen because it provides an unusual challenge to the ACF. The formulation politics surrounding the decision to construct the Animas-La Plata project followed the typical pattern of subsystem-based, distributive policymaking prevalent in western water politics (Ingram, 1972, 1990; Mann, 1975; McCool, 1994; Miller, 1985). A pro-water development coalition consisting of the Bureau of Reclamation, congressional committees, and local project proponents - such as state agencies and legislators, local governments, and farmers successfully have won authorization and a recent reauthorization of the project (United States Bureau of Reclamation, 1988).

But within the policy subsystem that controls the formulation and implementation of western water policy are advocacy coalitions that contest the power of the traditional pro-water development coalition. An environmental protection coalition, for example, composed of congress-persons and relevant committees, federal and state wildlife management agencies, and groups such as the Sierra Club Legal Defense Fund and the Environmental Defense Fund, works to protect endangered species. Hence, within the context of policy fragmentation and competition that typifies implementation, the challenge to the ACF will be its ability to explain subsystem activity during processes surrounding construction rather than authorization.

Implementation of the ESA (PL 93-205) vis-a-vis planning for the construction of the project has been complex. The Animas-La Plata project was authorized first in 1968, but construction delays have given officials in the U.S. Fish and Wildlife Service two opportunities to examine the 
project's impacts on endangered species. While these two examinations resulted in similar biological findings, the subsequent regulatory decisions were quite different and reveal how coalitions adopt new political strategies in the face of unanticipated complexity and policy change.(1)

\section{The Advocacy Coalition Framework}

The unit of analysis in the advocacy coalition framework is the policy subsystem. Policy subsystems are groups of formal and informal actors who are involved actively in substantive policy issues (Heclo, 1978; Sabatier, 1987). The concept of a policy subsystem goes beyond "subgovernments," or "iron triangles," since their membership is more dynamic and less formalistic: They are not closed and include individuals such as researchers and journalists who typically would be considered outside subgovernments (Sabatier, 1987, p. 652). The basic idea of the ACF is that policy actors within subsystems form alliances around core beliefs, or values, about what government should do. These alliances are called advocacy coalitions and tend to remain stable over a period of a decade or more (Sabatier, 1987, p. 651).

The purpose of the ACF is to explain policy change, which can occur in two ways. First, policy changes sometimes result from systemic change external to the subsystem, such as the rise of a new governing coalition (e.g., through elections) or change in the economy (Jenkins-Smith \& Sabatier, 1994, p. 183). External events cause policy change by creating the conditions necessary to produce new governing coalitions or new policy approaches. Alternatively, policy change also can occur when advocacy coalitions modify their beliefs and behaviors in response to activity within the subsystem. The ACF assumes that policy-oriented learning within the subsystem is "instrumental [as] members of various coalitions seek to better understand the world in order to further their policy objectives" (Sabatier \& Jenkins-Smith, 1997, p. 10).

The ACF theory includes several hypotheses that can be used to examine advocacy coalitions, policy change, and policy-oriented learning and that bear directly upon the implementation questions raised earlier. First, it is important to assess the stability of coalitions over time and across policy stages by comparing the content of policy outputs to the belief systems of subsystem participants. Since belief systems are difficult to change it can be assumed that policies will reflect the relative strength of each coalition (Davis \& Davis, 1988; Lertzman, Rayner, \& Wilson, 1996; Pal, 1995).

Belief systems operate on a tripartite, hierarchical basis "in which the most basic beliefs constrain more specific operational beliefs and policy positions" (Jenkins-Smith et al., 1991, p. 852). Deep core beliefs include the "basic ontological and normative beliefs" and are highly resistant to change (Sabatier \& Jenkins-Smith, 1997, p. 7). Policy core beliefs are the "glue" that hold advocacy coalitions together and reflect the coalition's normative commitments and causal perceptions (Sabatier \& Jenkins-Smith, 1997, pp. 7-8). Finally, the secondary aspects of belief systems reflect operational and institutional problems associated with policy design and implementation. Secondary aspects of belief systems are the least rigid components in the 
hierarchy and often are adapted or modified to meet emerging challenges and difficulties (Sabatier \& Jenkins-Smith, 1997, p. 8).

The ACF offers a number of hypotheses concerning belief systems, coalition stability, policy change, and policy-oriented learning. Since the focus of this paper is on coalition activity during implementation, especially the type of technical activity and debate that surrounds complex administrative process, the first two hypotheses serve primarily descriptive purposes. The third hypothesis provides a guideline for the analytical portion of the paper: examination of the ESA implementation process.

First, it is important to reveal the coalition participants, competing beliefs, and the stability of policy subsystems. Thus, the ACF offers the following hypothesis:

H1: On major controversies within a policy subsystem when policy core beliefs are in dispute, the lineup of allies and opponents tends to be rather stable over periods of a decade or so (Sabatier \& Jenkins-Smith, 1997 [H1]).

The next hypothesis focuses more specifically on policy change and the relationship between coalitions as external events threaten subsystem stability. As administrative events are analyzed, this hypothesis provides an important check on the influence that external events have on activities internal to the subsystem. The ACF predicts that policy change is unlikely if the relationships between advocacy coalitions remain stable during implementation:

$\mathrm{H}$ 2: The policy core attributes of a governmental program are unlikely to be significantly revised as long as the subsystem advocacy coalition which instituted the program remains in power (Sabatier \& Jenkins-Smith, 1997 [H4]).

Finally, the ACF predicts that policy-oriented learning can occur during the types of technical disputes that dominate administrative processes. Specifically, policy-oriented learning is enhanced when two or more coalitions have the technical capacity to participate in complex administrative processes and when secondary aspects of belief systems are in dispute:

H3: Policy-oriented learning across belief systems is most likely when there is an intermediate level of informed conflict between two coalitions. This requires that: (a) Each has the technical resources to engage in such a debate; and that (b) the conflict be between secondary aspects of one belief system and core elements of the other or, alternatively, between important secondary aspects of the two belief systems (Sabatier \& Jenkins-Smith, 1997 [H6]).

The analysis begins with a brief description of the Animas-La Plata water project and a discussion of how implementation of the ESA has impacted the project. Next, the dynamics of the bargaining process will be analyzed via the ACF and the hypotheses offered above.

\section{The Animas-La Plata Project and Implementation of the ESA}


The area known as Four Corners in southwestern Colorado and northwestern New Mexico is high and arid, and has few natural water resources. In Colorado the area is home to the Southern Ute and Ute Mountain Ute Indian Reservations, which lie in approximately 10-mile horizontal strips along the border with New Mexico. While several rivers transverse the reservations, flowing south into the San Juan River in New Mexico, only the Animas River has the stream flows necessary for regional agricultural development. Since most of the area's irrigable acreage lies along the drier La Plata River watershed to the west of the Animas, area farmers and municipalities have searched for ways to divert water from the Animas to the La Plata River (United States Department of the Interior, 1967). The Animas-La Plata water project was authorized for construction by Congress in 1968, along with the Central Arizona Project and four other Colorado water projects in the Colorado River Basin Project Act (United States Bureau of Reclamation, 1979, 1988).

Two early problems hindered the construction of the Animas-La Plata project. First, project construction was stalled in the early 1970s when the U.S. government, on behalf of the Southern Ute and Ute Mountain Ute Indian tribes, filed for adjudication of the Ute tribes' federal reserve water rights in Colorado District Court on the Animas, La Plata, and other rivers crossing the reservations.(2) Since the Ute reservations were established in 1868, well before non-Indian settlement in the area, the successful adjudication of these water rights by the federal government would give the Ute Indian tribes a higher priority for water use than their non-Indian neighbors (Decker, 1991; Lile, 1990).

During resolution of these water rights claims a second problem arose as the Carter and Reagan administrations questioned the economic feasibility of many western water development projects, including Animas-La Plata. In response to this presidential pressure and subsequent congressional legislation, the Bureau of Reclamation developed a program to increase the economic feasibility of the Animas-La Plata project that would split it into two phases (United States Bureau of Reclamation, 1988, p. 5). The first phase of the project would be constructed and financed by the federal government on a fixed schedule, while phase two would be financed by the states and built on a schedule "deemed practicable" (United States Bureau of Reclamation, 1986a, p. 4).

The litigation over the Ute Indian tribes' water rights and the cost-sharing issue were resolved in 1986 when the state of Colorado, local governments, representatives from the Ute Mountain Ute and Southern Ute Tribes, and representatives from the Departments of Justice and Interior signed the Colorado Ute Indian Water Rights Settlement Agreement (United States Bureau of Reclamation, 1986b). In exchange for the quantification of their water rights on the reservations, rights in the Animas-La Plata and Dolores water projects, and a \$49.5 million Tribal Development Fund, the Ute Indian tribes agreed to relinquish their water rights claims if phase one is constructed by the year 2000 (United States Bureau of Reclamation, 1986b). This agreement was ratified by Congress in the Colorado Ute Indian Water Rights Settlement Act of 1988 (PL 100-585).

Finally, the Animas-La Plata project is not the only incomplete water project in the San Juan River Basin. The massive Navajo Indian Irrigation Project (NIIP) was authorized in 1962 (PL 87-483) to provide agricultural and other economic development opportunities to the Navajo 
Nation. NIIP was designed originally to provide the Navajo Nation with the ability to irrigate 110,000 acres with 508,000 acre feet of water stored in Navajo Reservoir, but a dispute between the Bureau of Reclamation and the Bureau of Indian Affairs, the project's primary sponsor, over water supply estimates resulted in redesigned facilities. Knowledge of the relationship between the Navajo project and the Animas-La Plata project is critical for this case study because both projects affect the same population of endangered squawfish in the San Juan River. Thus, the Animas-La Plata project and the Navajo project are in competition with each other for construction funding and the favorable resolution of ESA administrative procedures (United States General Accounting Office, 1996), p. 23).

\section{ESA Implementation: Developing Water and Protecting Fish}

Problems with the protection of endangered fish species in the San Juan River Basin also have had a significant impact on construction of the Animas-La Plata project. The ESA requires that federal agencies consult with the U.S. Fish and Wildlife Service if their actions might impact listed species or habitat critical to their survival. After the consultation, the Service issues a biological opinion stating whether the action poses "jeopardy" or "no jeopardy" to the species. If the Service concludes that the action will harm the species or critical habitat, the action agency or the Service may suggest a "reasonable and prudent alternative" to the action designed to mitigate its negative impacts (50 CFR, Part 402, Final Rule, Federal Register, June 3, 1986; Tobin, 1990).

In 1979 the Service issued a "no jeopardy" biological opinion on the Animas-La Plata project. The findings of the opinion, however, were mixed. The Service stated that while the Animas-La Plata project would "further degrade the San Juan River to a point that this population [of squawfish] would be lost," it noted that the species would continue to exist in the Green and Colorado Rivers (United States Fish and Wildlife Service, 1979, p. 5). Thus, the squawfish population in the San Juan River was expendable because the fish were protected elsewhere. Still, the Service also concluded that the Bureau's conservation program for protecting squawfish habitat was "woefully negligent" and suggested a course of action to determine the extent and needs of the squawfish population in the San Juan River (United States Fish and Wildlife Service, 1979, pp. 5-6).

The Bureau did not begin its habitat research program on the San Juan River until 1987. That year, a group of researchers from the Bureau, Service, New Mexico Department of Game and Fish, and the University of New Mexico conducted an extensive biological survey of the river and found new evidence of squawfish reproduction (interview by author and S. P. Davis with J. Brooks, Project Leader, U.S. Fish and Wildlife Service, New Mexico Ecological Services Field Office, July 15, 1993; interview by author and S. P. Davis with D. Propst, Nongame Researcher, New Mexico Department of Game and Fish, R. Williams, Head of Fisheries, Utah Field Office, U.S. Fish and Wildlife Service, and J. Brooks, Project Leader, U. S. Fish and Wildlife Service, New Mexico Ecological Services Field Office, Albuquerque, NM, September 28, 1993; United States Fish and Wildlife Service, 1991). 
Since the ESA requires successive consultations as new biological information is collected, the research conducted on the San Juan River in 1987 gave Service biologists the opportunity to revisit issues addressed in the 1979 biological opinion. Most importantly, problems with implementation of the Service's squawfish protection program in the Upper Colorado River Basin forced the agency's biologists to reconsider their policy on the expendability of the squawfish population in the San Juan River. By 1990 Service biologists argued that the squawfish population on the San Juan River provided a critical reserve population in the event that the Green and Colorado River populations were lost (United States Fish and Wildlife Service, 1990b, pp. 14-15).

After the findings from the 1987 survey were reported, the Bureau consented to a second ESA consultation for the Animas-La Plata project. In the face of the Service's new position on the San Juan River squawfish population, members of the water development coalition expected the Service to reverse its 1979 "no jeopardy" opinion and issue a "jeopardy" opinion on the AnimasLa Plata project. A potential "jeopardy" biological opinion also meant that the Bureau and the Service would need to develop a "reasonable and prudent alternative" that would allow construction of the project to proceed in compliance with the Colorado Ute Indian Water Rights Settlement Act (interview by author and S. P. Davis with K. L. Rose, Assistant Colorado State Supervisor, U.S. Fish and Wildlife Service, Western Colorado Office, Grand Junction, CO, September 27, 1993; U.S. Fish and Wildlife Service, 1990b).

During the consultation the Service and the Bureau explored several options that could be used to develop a reasonable and prudent alternative. These opinions included the possibility of operational or design changes for Animas-La Plata and other Bureau projects, or a water exchange from Navajo Reservoir to benefit the squawfish. At issue is whether dams and reservoirs could be operated to resemble the natural hydrography of a river system. Service biologists contended that releases from reservoirs should be greater in the spring and lesser in the summer. These management ideas, however, were contrary to the very purpose of reservoir construction in the western United States, where the objective was to store spring runoffs for release to farmers late in the summer or to coincide with power demands (interview by author and S. P. Davis with J. Brooks, Project Leader, U. S. Fish and Wildlife Service, New Mexico Ecological Services Field Office, July 15, 1993; interview by author and S. P. Davis with D. Propst, Nongame Researcher, New Mexico Department of Game and Fish, R. Williams, Head of Fisheries, Utah Field Office, U.S. Fish and Wildlife Service, and J. Brooks, Project Leader, U.S. Fish and Wildlife Service, New Mexico Ecological Services Field Office, Albuquerque, NM, September 28, 1993; interview by author and S. P. Davis with K. L. Rose, Assistant Colorado State Supervisor, U.S. Fish and Wildlife Service, Western Colorado Office, Grand Junction, CO, September 27, 1993).

Both the Bureau and the Service rejected the options explored in the consultation. The Bureau cited long-standing management practices and poor hydrology, while the Service decided that they were not "biologically defensible" (United States Fish and Wildlife Service, 1990b; 1991, p. 27). Thus, in May 1990 tile Service issued a draft "jeopardy" biological opinion that did not include a "reasonable and prudent alternative." In concluding this issue, the Service stated in the draft biological opinion that "in most years the river is already at or below file threshold for minimum flows whereby the fish could survive in the river, any further depletions to the river 
system could render the San Juan River unusable by the Colorado squawfish" (United States Fish and Wildlife Service, 1990b, p. 22).(3)

\section{Development of a Reasonable and Prudent Alternative}

The Bureau was given a chance to respond to the draft biological opinion before the final version was released. Therefore, it assembled a team of fishery biologists and hydrologists from government agencies and private firms to review the findings of the draft biological opinion during the summer of 1990. The Bureau also updated its hydrological models and analyses of the San Juan River. based on the biological team's conclusions and the results from the updated modeling exercises, the Bureau agreed that the Animas-La Plata project posed a danger to the Colorado squawfish and that 300,000 acre feet of water could be made available at Navajo Dam to mimic the spring runoffs needed for recovery of the species. Additionally, the Bureau stated that it was willing to consider a reasonable and prudent alternative that limited construction of the Animas-La Plata project to three initial facilities - Ridges Basin Reservoir, Durango Pumping Plant, and the inlet conduit - and limited initial depletions from the Animas River (United States Fish and Wildlife Service, 1991).

In the face of these revelations, the Bureau initiated a process in September 1990 in which project proponents, the Service, and personnel from state wildlife agencies would develop a reasonable and prudent 'alternative for the final "jeopardy" biological opinion. Three committees were formed to examine the critical issues - biology, hydrology, and legality - and a management task force was established to oversee the process and track progress (United States Fish and Wildlife Service, 1991, p. 29).

As the most critical group in the process, the biology committee's approval of any proposed reasonable and prudent alternative was essential (interview by the author and S. P. Davis with R. Bethel, Principal, Leonard Rice Consulting Water Engineers, Inc., Denver, CO, September 9, 1993). The biology committee eventually agreed to a reasonable and prudent alternative that contains five elements: (1) limit construction of the Animas-La Plata project to three features Ridges Basin Reservoir, Durango Pumping Plant, and the inlet conduit - and to limit initial depletions to 57,100 acre feet; (2) fund a 7-year research effort on the San Juan River and its tributaries; (3) operate Navajo Dam for the duration of the research period to mimic the natural hydrography of the San Juan River; (4) operate Navajo Dam for the benefit of the Colorado squawfish for the life of the Animas-La Plata project; and (5) develop a recovery implementation program for the Colorado squawfish on the San Juan River (United States Fish and Wildlife Service, 1991, pp. 32-33).

This proposal originally was rejected by the Bureau and labeled "biologically indefensible" by Service biologists in the draft opinion (United States Fish and Wildlife Service, 1990b, pp. 2122). How Bureau engineers and Service biologists eventually sanctioned this proposal requires an understanding of subsystem politics and the intricacies of administrative procedure. 


\section{The Advocacy Coalition Framework and Implementation of the ESA}

The purpose of this paper is to use the advocacy coalition framework to examine the stability of policy-producing coalitions over time in the face of implementation complexities. The following sections will focus on the ACF visa-vis the hypotheses on advocacy coalitions (H1), policy change $(\mathrm{H} 2)$, and policy learning $(\mathrm{H} 3)$.

\section{Advocacy Coalitions}

The results of the consultation reveal some interesting directions for the construction of the Animas-La Plata project and the protection of endangered species. H1 states that:

On major controversies within a policy subsystem when policy core beliefs are in dispute, the lineup of allies and opponents tends to be rather stable over periods of a decade or so (Sabatier \& Jenkins-Smith, 1997 [H1]).

\section{Coalitions}

For the Animas-La Plata project the water resources development coalition is composed of: Colorado's congressional delegation; the state governor; many legislators in the Colorado General Assembly; officials in the Bureau of Reclamation and on the Colorado Water Conservation Board; local proponents such as the city of Durango, Colorado and the Animas-La Plata Water Conservation District; and the Southern Ute and Ute Mountain Ute Indian tribes.

In the case of ESA implementation for the Animas-La Plata project, two important advocacy coalitions have emerged to compete within the subsystem for their stake in the policy contest. An environmental protection coalition is composed of: officials from the U.S. Fish and Wildlife Service, officials from Colorado's and New Mexico's wildlife management agencies, university researchers, and national and regional environmental interest groups such as the Environmental Defense Fund and the local Four Comers Action Coalition. Members of this coalition have worked to protect en 'dangered species that would be harmed by the project.

Another subsystem participant can be called the Native American water development coalition (McCool, 1994). This coalition is composed of: a few members of Congress, officials from the Bureau of Indian Affairs, and in this case, the Navajo Nation and other tribes in the San Juan River Basin. Within the context of the Animas-La Plata project, the Native American water development coalition has struggled to protect Navajo water rights and the future viability of the Navajo Indian Irrigation Project. The policy struggle over the Animas-La Plata project is problematic for the Native American water coalition because it pits Native Americans against each other in the competition for the development of water resources (interview by author and S. P. Davis with J. D. Little, Rights Protection Manager, Bureau of Indian Affairs, and R. Johnson, Assistant Area Director for Programs, Bureau of Indian Affairs, U.S. Bureau of Indian Affairs, 
Albuquerque Area Office, Albuquerque, NM, July 14, 1993; interview by author and S. P. Davis with L. Taylor, attorney, law offices of Nordhaus, Haltom, Taylor, Taradash, \& Frye, Albuquerque, NM, May 17, 1994; interview by author and S. P. Davis with T. Vollman, Regional Solicitor, Southwest Region, U.S. Department of the Interior, Regional Solicitor's Office, Albuquerque, NM, May 18, 1994; interviews by the author, S. P. Davis, \& S. Naiberk [Window Rock, AZ, Navajo tribal headquarters] with P. Zah, president, Navajo Nation, S. Pollack, special council for water rights, T. Showa, director, water resources management, M. Johnson, hydrologist, and M. Tremble, wildlife manager, January 12, 1994).

\section{Beliefs}

At the heart of the ACF is the assumption that the advocacy coalitions are held together through agreement on policy core beliefs (Sabatier \& Jenkins-Smith, 1997). Policy core beliefs came into conflict during the consultation as the Service threatened to stop construction of the Animas-La Plata project in the draft "jeopardy" biological opinion. In competition is the environmental protection coalition's policy core belief in saving endangered species versus the water development coalition's policy core belief that government should develop water resources.

The 1979 biological arrangement allowed both coalitions to defer resolution of the endangered species issues. For their part, the water resources development coalition was willing to gamble that project construction would begin before the issue could be revisited. But as the second consultation began in 1990, the Service had learned a good deal more about protecting the Colorado squawfish and its habitat during implementation of the squawfish recovery program for the Upper Colorado River Basin (interview by author and S. P. Davis with J. Brooks, Project Leader, U.S. Fish and Wildlife Service, New Mexico Ecological Services Field Office, July 15, 1993; interview by author and S. P. Davis with D. Propst, Nongame Researcher, New Mexico Department of Game and Fish, R. Williams, Head of Fisheries, Utah Field Office, U.S. Fish and Wildlife Service, and J. Brooks, Project Leader, U.S. Fish and Wildlife Service, New Mexico Ecological Services Field Office, Albuquerque, NM, September 28, 1993; interview by author and S. P. Davis with K. L. Rose, Assistant Colorado State Supervisor, U.S. Fish and Wildlife Service, Western Colorado Office, Grand Junction, CO, September 27, 1993; United States Fish and Wildlife Service, 1990c). This experience gave Service biologists the ability to engage the water development coalition more effectively than they had in 1979, but not to win the policy conflict outright.

Both the water development and environmental protection coalitions protected their policy core beliefs by making adjustments in secondary aspects of their belief systems. Both coalitions changed their management practices but not their policy objectives. The environmental protection coalition accepted a "biologically indefensible" reasonable and prudent alternative, but gained additional funding for recovery efforts and alterations in the Bureau's longstanding water management practices. The Animas-La Plata project water development coalition was given an opportunity to begin construction on the project in the face of a serious threat to the endangered Colorado squawfish. 


\section{Stability}

During the course of the ESA implementation process for the Animas-La Plata water project the lineup of allies and opponents in the policy subsystem has remained quite stable. During the 1979 consultation, the Service challenged the Bureau to continue its biological research in the San Juan River Basin and to improve its habitat management program. Thus, the alignment of coalitions within the policy subsystem did not change with the release of the $1990 \mathrm{draft}$ biological opinion on the Animas-La Plata project.

\section{Policy Change}

The ACF theory asserts that policy change can occur in response to external events or from policy-oriented learning. Hence, the next hypothesis focuses on the governing coalition's ability to maintain control of the program in the face of external instability:

$\mathrm{H} 2$ : The policy core attributes of a governmental program are unlikely to be significantly revised as long as the subsystem advocacy coalition which instituted the program remains in power (Sabatier \& Jenkins-Smith, 1997 [H4]).

Between the release of the first "no jeopardy" opinion in 1979 and the second "jeopardy" opinion in 1991, there were two critical events that challenged the ability of the water resources development coalition to maintain control of the Animas-La Plata program. First, when the Service changed its position and decided that the San Juan River squawfish population was critical to the recovery effort, it changed the balance of power between the Animas-La Plata water development and environmental protection coalitions. Suddenly, the environmental coalition was given the opportunity to challenge the Bureau's water management practices, which, according to several biologists who worked on the consultation, was the primary goal of the draft "jeopardy" opinion (interview by author and S. P. Davis with J. Brooks, Project Leader, U.S. Fish and Wildlife Service, New Mexico Ecological Services Field Office, July 15, 1993; interview by author and S. P. Davis with D. Propst, Nongame Researcher, New Mexico Department of Game and Fish, R. Williams, Head of Fisheries, Utah Field Office, U.S. Fish and Wildlife Service, and J. Brooks, Project Leader, U.S. Fish and Wildlife Service, New Mexico Ecological Services Field Office, Albuquerque, NM, September 28, 1993; interview by author and S. P. Davis with K. L. Rose, Assistant Colorado State Supervisor, U.S. Fish and Wildlife Service, Western Colorado Office, Grand Junction, CO, September 27, 1993).

The second critical external event that occurred between 1979 and 1990 was concerns expressed by presidents Carter and Reagan about the economic feasibility of western water projects. Their challenge led to the development of the Cost Sharing Agreement, and ultimately to the passage of the Colorado Ute Indian Water Rights Settlement Act. This new Animas-La Plata project authorization provided the water resources development coalition with important resources that proved to be pivotal in later negotiations concerning project compliance with environmental 
protection regulations. Most importantly, the statute gave the Bureau a mandate to build the project without regard to standard cost-benefit criteria. Indeed, in testimony on the 1988 legislation the Secretary of the Interior acknowledged that "the Animas-La Plata project is not economically feasible under current discount rates," but still decided to support the project because it would "provide a means to satisfy the water claims of the Colorado Ute tribes while leaving intact the historical uses already in place on these streams" (United States Congress, 1988, p. 19). Ultimately, the reauthorization of the project allowed Bureau officials to use an "Indians versus fish" argument that placed enormous pressure on the environmental protection coalition to support a reasonable and prudent alternative that would allow construction to begin on the project (interview by author and S. P. Davis with J. Brooks, Project Leader, U.S. Fish and Wildlife Service, New Mexico Ecological Services Field Office, July 15, 1993; interview by author and S. P. Davis with D. Propst, Nongame Researcher, New Mexico Department of Game and Fish, R. Williams, Head of Fisheries, Utah Field Office, U.S. Fish and Wildlife Service, and J. Brooks, Project Leader, U.S. Fish and Wildlife Service, New Mexico Ecological Services Field Office, Albuquerque, NM, September 28, 1993; interview by author and S. P. Davis with K. L. Rose, Assistant Colorado State Supervisor, U.S. Fish and Wildlife Service, Western Colorado Office, Grand Junction, CO, September 27, 1993).

\section{Policy-Oriented Learning}

Although policy change did occur, the evidence suggests that the impact of external events on subsystem stability was a trade-off for the water development and environmental protection coalitions. The final hypothesis suggests that policy-oriented learning is most likely to occur during informed conflict when competing coalitions have the technical resources to participate in complex debates and the leeway to make choices about secondary aspects of belief systems (Jenkins-Smith \& Sabatier, 1994, p. 184).

H3: Policy-oriented learning across belief systems is most likely when there is an intermediate level of informed conflict between two coalitions. This requires that: (a) Each have the technical resources to engage in such a debate; and that (b) the conflict be between secondary aspects of one belief system and core elements of the other or, alternatively, between important secondary aspects of the two belief systems (Sabatier \& Jenkins-Smith, 1997 [H6]).

The central concern of this paper is the nature of subsystem activity during policy implementation, which will be addressed by examining the consultation process.

The ESA consultation on the Animas-La Plata water project presented officials in the Bureau of Reclamation with the ultimate challenge of how to turn water scarcity into plenitude. Since the primary justification for western water projects was water scarcity, the Bureau had to demonstrate to Congress that the Animas-La Plata project would serve an area that suffers from a shortage of water. This was done through two primary documents: the 1967 Feasibility Report to Congress (United States Department of the Interior, 1967) and the 1979 Definite Plan Report (United States Bureau of Reclamation, 1979). Both documents used hydrological analyses of the San Juan River and its tributaries to reveal inefficiencies in the system that can be corrected with 
strategically constructed dams, reservoirs, and other infrastructure. These hydrological models also were used by the Service during the 1979 and 1990 consultations, and in both cases it determined that water scarcity would result in the demise of the squawfish (United States Fish and Wildlife Service, 1979, 1991).

The scarcity argument was not a problem for Bureau officials when the squawfish population on the San Juan River was considered expendable, but when the 1990 draft biological opinion on the Animas-La Plata project was released without a reasonable and prudent alternative, Bureau officials were faced with a crisis. How could they demonstrate that the Service had misinterpreted their hydrological information, and that plenty of water could be made available for the protection of squawfish habitat? The Bureau's first response was to admit that the hydrological models used to justify project construction were incorrect. This determination led to the generation of "new hydrological information" and "updated hydrology modeling" that could be used to develop a reasonable and prudent alternative (United States Fish and Wildlife Service, 1991, p. 28). Second, the Bureau created a process that allowed them to control the flow of information critical to the development of the reasonable and prudent alternative and the final biological opinion.

After the release of the draft biological opinion, the Bureau's control of the information used to develop hydrology for the reasonable and prudent alternative went together with its control of the process. As described earlier, once the Service revealed its inclination to release a biological opinion without a reasonable and prudent alternative, the Bureau effectively took control of the consultation process away from the Service by assembling three interagency teams to focus on each aspect of the problem. The biology committee was composed of federal and state biologists representing the Service, the Bureau, New Mexico, Colorado, and consultants hired by the local project proponents. The hydrology committee was composed mostly of Bureau and Service hydrologists and consultants hired by the local project proponents. A legal committee also was created to collect legal information related to the project (interview by the author and S. P. Davis with R. Bethel, Principal, Leonard Rice Consulting Water Engineers, Inc., Denver, CO, September 9, 1993; interview by author and S. P. Davis with D. Propst, Nongame Researcher, New Mexico Department of Game and Fish, R. Williams, Head of Fisheries, Utah Field Office, U.S. Fish and Wildlife Service, and J. Brooks, Project Leader, U.S. Fish and Wildlife Service, New Mexico Ecological Services Field Office, Albuquerque, NM, September 28, 1993; interview by author and S. P. Davis with K. L. Rose, Assistant Colorado State Supervisor, U.S. Fish and Wildlife Service, Western Colorado Office, Grand Junction, CO, September 27, 1993).

The first piece of information given to these committees was the Bureau's "new hydrological information," which revealed that "300,000 acre feet of water could be made available from Navajo Reservoir to re-create the spring peak flows in the San Juan River" (United States Fish and Wildlife Service, 1991, p. 28). Next, the hydrology committee developed a model that was used to study stream flows on the San Juan River and its tributaries. The model the hydrology committee developed was essentially a spreadsheet that accounted for depletions and inflows into the San Juan River. Examples of diversions included municipal and industrial water supplies taken from the river, irrigation, power plants, etc. Examples of inflows included rivers, such as the Animas and La Plata that flow into the San Juan, agricultural return flows, and releases from Navajo Reservoir. Data for this model were readily available, since the U.S. Geological Survey 
had collected information on streamflows in the San Juan River Basin since 1914 (United States Bureau of Reclamation, 1979). Finally, reasoning that the San Juan River had reached its maximum capacity for development, the sum of these inflows and depletions was used to create an environmental baseline by which all future projects would be measured (interview by the author and S. P. Davis with R. Bethel, Principal, Leonard Rice Consulting Water Engineers, Inc., Denver, CO, September 9, 1993).

Because the model was based on an accounting of current and potential uses of water, it was highly susceptible to manipulation through changes in assumptions. Historically, for example, the Bureau has respected "prior nonproject water rights" in analyses of the San Juan River. Thus, if the Bureau conducted a hypothetical analysis of the San Juan-Chama project's impacts on the San Juan River, it would account for the Animas-La Plata project's needs of 154,800 acre feet per year, even though the project has not been constructed, in order to protect the intentions and rights of other water developers.

In the hydrological model developed to support the reasonable and prudent alternative, the hydrology committee made several unusual methodological decisions that changed the old scenario of water scarcity in the San Juan River to one of plenitude. First, the hydrology committee dropped the Bureau's long-time policy of respect for prior nonproject water rights in the model and borrowed heavily from water historically reserved for the Navajo Nation. Second, the committee chose to model the river using a period of record, 19351962, that preceded the construction of Navajo Reservoir, even though data used in other modeling exercises had been from 1929 to 1977 (interview by the author and S. P. Davis with R. Bethel, Principal, Leonard Rice Consulting Water Engineers, Inc., Denver, CO, September 9, 1993). This is even more curious because the purpose of the modeling exercise was to evaluate the impact of the proposed 300,000-acre-foot spill on a regulated river, not a virgin river as existed before Navajo Reservoir came on-line in 1963. The result of these changes can be traced as follows (see Table 1).

The hydrology committee met on October 17, 1990 and assessed the original numbers used in their modeling exercise. The first number, 921,000 acre feet, reflects a full accounting of all water rights, developed and undeveloped, in the San Juan River Basin (out of a potential of 1.9 million acre feet).(4) The second number, 254,000 acre feet, reflects the amount of water the Bureau had allocated for development of the NIIP. By the time the hydrology committee revealed its model in a meeting on December 19, 1990, the baseline depletion had decreased by over 300,000 acre feet and the NIIP allocation had decreased by 100,000 acre feet. Finally, in addition to other prior project water rights that were eliminated from consideration, the hydrology committee's model did not include a depletion lot the Animas-La Plata project, another prior nonproject water right, even though the objective of the exercise was to develop a scenario that would allow for the construction of the full project.

\section{[TABULAR DATA FOR TABLE 1 OMITTED]}

After the model was constructed the hydrology committee served as a response team in the development of a reasonable and prudent alternative. Bureau officials would offer possible depletions for the Animas-La Plata project, and the hydrology committee would run these suggestions though the model to determine the net effect on the San Juan River. Once the effect 
of a possible diversion was determined, the hydrology committee gave the information to the biology committee "to see if they could live with it" (interview by the author and S. P. Davis with R. Bethel, Principal, Leonard Rice Consulting Water Engineers, Inc., Denver, CO, September 9, 1993). Eventually, due to the inexact nature of biological science, a depletion level for the Animas-La Plata project was found that seemed to have no impact on the San Juan River. Indeed, members of the biology committee, after assessing the Bureau's final offer, stated that:

The determination that an additional 60,300 [acre feet] depletion can proceed in the San Juan River Basin was based solely on a modeling exercise that when coupled with a commitment to reoperate Navajo Dam to mimic a natural hydrography, showed that current flow conditions of the San Juan River Basin did not appreciably change and moreover appeared to improve river conditions (United States Fish and Wildlife Service, 1990a, p. 5).

Thus, although it was forced to make important concessions, the water resources development coalition's control of the information and the consultation process gave it the ability to ignore prior nonproject water rights; commit to the reoperation of Navajo Reservoir, commit funding for a 7-year research effort, and confidently offer to construct only part of the project.

Furthermore, the Bureau was able to secure a deal for project construction even in the face of outside sources of resistance. During the consultation, both the solicitor for the Department of the Interior's Southwest Region and the Assistant Secretary for Indian Affairs expressed concern that Navajo water rights were not considered adequately during the 1990-1991 Animas-La Plata consultation (United States General Accounting Office 1996, p. 24; interview by author and S. P. Davis with T. Vollman, Regional Solicitor, Southwest Region, U.S. Department of the Interior, Regional Solicitor's Office, Albuquerque, NM, May 18, 1994).

The ESA consultation process between the Bureau of Reclamation and the Service revealed the disparities in the technical resources of the participants and the dynamics of policy subsystems during implementation. Service biologists and other members of the environmental protection coalition, for example, were unable to provide the precise responses that Bureau engineers wanted when the hydrological and biological data were compared and analyzed. This gave the engineers an advantage in the process, but at the same time it was the very development of biological data and related technical resources that gave the Service the advantage in the larger administrative process. Several government biologists involved in the process noted that it has taken the Service 20 years to learn how to implement the ESA, and that as the Service has gotten better at understanding the biology of protecting endangered species it has taken a more dominant role in the consultation process (interview by author and S. P. Davis with J. Brooks, Project Leader, U.S. Fish and Wildlife Service, New Mexico Ecological Services Field Office, July 15, 1993; interview by author and S. P. Davis with D. Propst, Nongame Researcher, New Mexico Department of Game and Fish, R. Williams, Head of Fisheries, Utah Field Office, U. S. Fish and Wildlife Service, and J. Brooks, Project Leader, U. S. Fish and Wildlife Service, New Mexico Ecological Services Field Office, Albuquerque, NM, September 28, 1993; interview by author and S. P. Davis with K. L. Rose, Assistant Colorado State Supervisor, U.S. Fish and Wildlife Service, Western Colorado Office, Grand Junction, CO, September 27, 1993).

Thus, the awkward "reasonable and prudent alternative" that neither protects endangered fish nor allows for the complete construction of the project is a reflection of conflict between the policy 
core beliefs of two competing coalitions and the resultant acquiescence on secondary aspects of their belief systems. The water development coalition, for example, is still in the process of constructing the Animas-La Plata project despite two consultations that concluded the project would destroy habitat critical to the survival of the Colorado squawfish. To achieve a construction start for the project, however, the Animas-La Plata water development coalition had to concede its long-standing contention that stored water resources must be managed for farmers and municipalities, not for endangered species. Similarly, the environmental protection coalition was forced to give the Bureau an opportunity to begin the incremental construction of the project, even though biologists have concluded that the Animas-La Plata project and the Colorado squawfish cannot coexist.

\section{Conclusion}

This analysis of subsystem dynamics is complex, and out of the miasma of events and activities that can affect policy implementation it describes only one: the impact of the ESA on the construction of the Animas-La Plata project. In reality there is no such thing as policy implementation, but instead there are multiple policy implementations. The congressional decision to construct the Animas-La Plata project is implemented alongside and among congressional decisions to protect endangered species, clean water, clean air, and cultural resources, to deliver subsidies to reservation economies, etc. As Kingdon (1984, p. 125) noted in his book on agenda setting, seemingly a long way from implementation, policy fragmentation is an inevitable consequence of fragmented policymaking communities, in which "the left hand knows not what the right hand is doing, with the result that the left hand sometimes does something that profoundly affects the right hand, without anyone ever seeing the consequences."

Policy subsystems are fragmented policymaking communities, and each coalition is involved actively in the formulation, implementation, evaluation, and manipulation of public policy. Hence the most important contribution of the advocacy coalition framework is that it transforms the language of policy study. Policy implementation is not a stage in the policy process, but a description of coalition activity that is not mutually exclusive of other policy activities. Indeed, Sabatier and Jenkins-Smith contend that the ACF "emerged out of a search for an alternative to the stages heuristic" and an attempt to incorporate the role of learning into policy activity (Sabatier \& Jenkins-Smith, 1997, p. 2; 1994).

The purpose of this study of subsystem activity and of the Animas-La Plata project was to bridge the gap between formulation and implementation and to examine how subsystems work during implementation. Interestingly, as Sabatier and Jenkins-Smith suggest, there is no gap between these activities. The examination of the Animas-La Plata project is a study in policy formulation/implementation, as the project constantly was being redesigned and reorganized in response to implementation difficulties. What was once a $\$ 700$ million monolith of dams, reservoirs, pumping stations, canals, and acres of irrigated fields is now a reservoir and a pumping station with no water delivery system nor a single irrigated acre. 
The advocacy coalition that won authorization of the Animas-La Plata project has remained stable throughout a plethora of challenge to its activities. Unless exogenous events displace governing coalitions, the ACF prediction that policy core beliefs hold coalitions together was affirmed by the Animas-La Plata case study. In the face of policy-oriented learning during implementation, the water development coalition conceded secondary aspects of its belief system to maintain the viability of its primary policy objective, construction of the AnimasLa Plata project. Bending on the secondary aspects of its belief system, however, demonstrates that coalition strength during policy formulation does not necessarily lead to strength during implementation. In 1988 Congress reaffirmed its commitment to the construction of the entire Animas-La Plata project, but the distributive playing field that dominated policy formulation became a regulatory playing field during implementation, shifting power to a regulatory coalition with regulatory policies to implement. Hence, coalition survival during implementation, especially in the face of unanticipated complexity, requires learning and the ability to adapt to changing policy conditions.

\section{Notes}

In order to provide a forum for replication and further academic review, the data collected for this article can be obtained by contacting the author at: Department of Political Science, Southwest Missouri State University, 901 South National Avenue, Springfield, Missouri 65804.

1 The data used for this paper were collected while I worked on an evaluation of the Animas-La Plata water project for the United States General Accounting Office (GAO) (1996). I am indebted to my colleagues and friends at the GAO, Sue E. Naiberk and Sandra P. Davis, for their contributions to this article. I also would like to thank Professors Diane Schmidt, Jill Glathar, Mark Rushefsky, Charles Davis, and Darnel McCool for their comments and suggestions on this paper.

2 In Winters v. United States (1908), the United States Supreme Court ruled that the water rights needed for the intended use of a federal reserve were established simultaneously when Congress set aside the land. These water rights, known as federal reserve water rights, "date from the year Congress created a reservation and exist whether or not Indians have put the water to beneficial use" (Jacobsen, 1992, p. 826). A methodology for quantifying federal reserve water rights on Indian reservations was established in Arizona v. California (1963). The Supreme Court ruled that a tribe is entitled to water for its practicable irrigable acreage, which often surpasses the amount of water available on the reservation (Feldman, 1994; Jacobsen, 1992; McCool, 1994).

3 The primary reason for this impasse was the needs of the Colorado squawfish. As the world's largest minnow - it can grow to over 5 feet in length - the Colorado squawfish survives in river systems that historically have had great variations in seasonal flow. In the summers, for example, the San Juan River once was reduced to a trickle, while springtime brought vast amounts of water to the river when mountain snowpacks melted. It has been documented that squawfish reproduction increases after high spring flows have flooded the lands along the river and muddied the water. The combination of silt, seasonal pulses of water, and access to flooded areas 
makes conditions right for reproduction. Biologists believe that the free-flowing Animas River, the only substantial unregulated river in the San Juan River Basin, has helped the squawfish survive (interview by author and S. P. Davis with J. Brooks, Project Leader, U.S. Fish and Wildlife Service, New Mexico Ecological Services Field Office, July 15, 1993; interview by author and S. P. Davis with S. Platania, professor, Department of Biology, University of New Mexico, Albuquerque, NM, May 18, 1994; interview by author and S. P. Davis with D. Propst, Nongame Researcher, New Mexico Department of Game and Fish, R. Williams, Head of Fisheries, Utah Field Office, U.S. Fish and Wildlife Service, and J. Brooks, Project Leader, U.S. Fish and Wildlife Service, New Mexico Ecological Services Field Office, Albuquerque, NM, September 28, 1993; United States Fish and Wildlife Service, 1991, pp. 10-13).

4 Table and analysis of the consultation process by the author and Sandra P. Davis, Senior Evaluator, United States General Accounting Office.

\section{References}

Arizona v. California, 373 U.S. 546 (1963); 103 S. Ct. 1382 (1983).

Cater, D. (1964). Power in Washington. New York, NY: Random House.

Davis, C., \& Davis, S. (1988). Analyzing change in public lands policy making: From subsystems to advocacy coalitions. Policy Studies Journal, 17, 3-24.

Decker, J. C. (1991, March 21-23). Conflicts in the Department of the Interior: Water project, Indian trust responsibility, and squawfish. Paper presented at the Western Political Science Association, Seattle, WA.

Feldman, S. M. (1994). The Supreme Court's new sovereign immunity doctrine and the McCarran amendment: Toward ending state adjudication of Indian water rights. Harvard Environmental Law Review, 18, 433-488.

Freeman, J. L. (1965). The political process [Rev. ed.]. New York, NY: Random House.

Griffith, E. S. (1939). The impasse of democracy. New York, NY: Harrison-Hilton.

Heclo, H. (1978). Issue networks and the executive establishment. In A. King (Ed.), The new American political system (pp. 87-124). Washington, DC: American Enterprise Institute for Public Policy Research.

Ingram, H. (1972). The changing decision rules in the politics of water development. Water Resources Bulletin, 8, 1177-1188.

Ingram, H. (1990). Water politics Continuity and change. Albuquerque, NM: University of New Mexico Press. 
Jacobsen, J. (1992). The Navajo indian Irrigation Project and quantification of Navajo Winters fights. Natural Resources Journal, 32, 825-853.

Jenkins-Smith, H., \& Sabatier, P. A. (1994). Evaluating the advocacy coalition framework. Journal of Public Policy, 14, 175-203.

Jenkins-Smith, H. C., St. Clair, G. K., \& Woods, B. (1991). Explaining change in policy subsystems: Analysis of coalition stability and defection over time. American Journal of Political Science, 35, 851-880.

Kingdon, J. W. (1984). Agendas, alternatives, and public policies. Glenview, IL: Scott, Foresman and Company.

Lertzman, K., Rayner, J., \& Wilson, J. (1996). Learning and change in British Columbia forest policy sector: A consideration of Sabatier's advocacy coalition framework. Canadian Journal of Political Science, 29, 111-133.

Lile, D. C. (1990). Colorado Ute Indian settlement. Denver, CO: Colorado Water Conservation Board.

Mann, D. E. (1975). Political incentives in U.S. water policy: Relationships between distributive and regulatory politics. In M. Holden, Jr. \& D. L. Dresang (Eds.), What government does (pp. 94-123). Beverly Hills, CA: Sage.

Mazmanian, D., \& Sabatier, P. (1989) Implementation and public policy. Lanham, MD: University Press of America.

McCool, D. (1990). Subgovernments as determinants of political viability. Political Science Quarterly, 105, 269-293.

McCool, D. (1994). Command of the waters: Iron triangles, federal water development, and Indian water. Tucson, AZ: University of Arizona Press.

McCool, D. (1997, March). Subsystem theory and the hierarchy of conflict. Paper presented at the Western Political Science Association Annual Meeting, Tucson, AZ.

Miller, T. (1985). Recent trends in federal water resource management: Are the iron triangles in retreat? Policy Studies Review, 5, 395-412.

Munro, J. (1993). California water politics: Explaining policy change in a cognitively polarized subsystem. In P. Sabatier \& H. Jenkins-Smith (Eds.), Policy change and learning (pp. 105-128). Boulder, CO: Westview.

Pal, L. A. (1995). Competing paradigms in policy discourse: The case of international human rights. Policy Sciences, 28, 185-207. 
Sabatier, P. (1987). Knowledge, policy-oriented learning, and policy change. Knowledge. Creation, Diffusion, Utilization, 8, 649-692.

Sabatier, P., \& Jenkins-Smith, H. (Eds.). (1993). Policy change and learning. Boulder, CO: Westview.

Sabatier, P. A., \& Jenkins-Smith, H. C. (1997, February). The advocacy coalition framework: An assessment. Paper presented at the Department of Political Science, University of Amsterdam.

Tobin, R. (1990). The expendable future: U.S. politics and the protection of biological diversity. Durham, NC: Duke University Press.

United States Bureau of Reclamation. (1979). Definite plan report: Animas-La Plata ProjectColorado and New Mexico. Denver, CO: United States Bureau of Reclamation.

United States Bureau of Reclamation. (1986a). Agreement in principle concerning Ire Colorado Ute Indian Water Rights Settlement and Binding Agreement for Animas-La Plata Cost Sharing. Denver, CO: United States Bureau of Reclamation.

United States Bureau of Reclamation. (1986b). Colorado Ute Indian Water Rights Settlement Agreement. Denver, CO: United States Bureau of Reclamation.

United States Bureau of Reclamation (1988). Animas-La Plata Project-Colorado and New Mexico. Special report. Denver, CO: United States Bureau of Reclamation.

United States Congress. (1988). Colorado Ute Indian Water Rights Settlement Act of 1987. Senate Report No. 100-555. Washington, DC: United States Government Printing Office.

United States Department of the Interior. (1967). Report to Congress on the Animas-La Plata Project, Colorado-New Mexico: Pursuant to the provisions of 53 Stat. 1187. Washington, DC: United States Department of the Interior.

United States Fish and Wildlife Service. (1979). Biological opinion for the Animas-La Plata Project, Colorado and New Mexico Albuquerque, NM: United States Fish and Wildlife Service.

United States Fish and Wildlife Service. (1990a, December 6-7). Animas-La Plata project, Endangered Species Act section 7 consultation. Biology committee minutes. Albuquerque, NM: United States Fish and Wildlife Service.

United States Fish and Wildlife Service. (1990b). Draft biological opinion for the Animas-La Plata Project, Colorado and New Mexico. Denver, CO: United States Fish and Wildlife Service.

United States Fish and Wildlife Service. (1990c). Recovery implementation program for endangered species in the Upper Colorado River Basin. Denver, CO: United States Fish and Wildlife Service. 
United States Fish and Wildlife Service. (1991). Final biological opinion for the Animas-La Plata Project, Colorado and New Mexico. Denver, CO: United States Fish and Wildlife Service.

United States General Accounting Office. (1996). The Animas-La Plata Project: Status and legislative framework. GAO/RCED-96-1. Washington, DC: United States General Accounting Office.

Winters v. United States, 207 U.S. 564 (1908). 